\title{
Occurrence of Ehrlichia canis in free-living primates of the genus Callithrix
}

\author{
Ocorrência de Ehrlichia canis em primatas de vida livre pertencentes ao gênero Callithrix \\ Claudio Mafra ${ }^{1 *}$; Rafael Mazioli Barcelos ${ }^{1}$; Cynthia Mantovani ${ }^{1}$; Juliana Carrizo ${ }^{1}$; Adriano Carlos Soares ${ }^{1}$; \\ Higo Nasser Sant'Anna Moreira' ${ }^{1}$ Natasha Lagos Maia²; Fernanda de Fátima Rodrigues da Silva ${ }^{3}$; \\ Vinícius Herold Dornelas e Silva ${ }^{3}$; Vanner Boere ${ }^{1}$; Ita de Oliveira e Silva ${ }^{3}$
}

\begin{abstract}
${ }^{1}$ Departamento de Bioquímica e Biologia Molecular, Universidade Federal de Viçosa - UFV, Viçosa, MG, Brasil
${ }^{2}$ Departamento de Medicina Veterinária, Universidade Federal de Viçosa - UFV, Viçosa, MG, Brasil

${ }^{3}$ Departamento de Biologia Animal, Universidade Federal de Viçosa - UFV, Viçosa, MG, Brasil
\end{abstract}

Received June 12, 2014

Accepted November 13, 2014

\begin{abstract}
Bacteria of the genus Ehrlichia are Gram-negative and coccoid-shaped microorganisms that cause ehrlichiosis - a serious infectious disease that often leads to death. These bacteria present a strong zoonotic potential and primates may act as reservoir hosts. This study involved a molecular analysis to detect these microorganisms in blood samples collected from nineteen primates of the genus Callithrix living free in an Atlantic Forest fragment in the municipality of Viçosa, state of Minas Gerais, Brazil. One of the 19 primates was found to be infected with Ehrlichia canis. This finding points to a new wild host of E. canis with a strong potential for transmission to humans because of its increasing contact with people. This is the first report of Ehrlichia spp. in primate of the genus Callithrix.
\end{abstract}

Keywords: Ehrlichia, Callithrix, marmoset, ticks.

\section{Resumo}

Bactérias do gênero Ehrlichia são gram-negativas em forma de cocos. Provocam uma doença infecciosa grave denominada erliquiose que, muitas vezes, causa morte. Essas bactérias apresentam grande potencial zoonótico, e os primatas podem agir como reservatórios. Este estudo objetivou a detecção molecular desse microorganismo em amostras de sangue coletadas de dezenove primatas de vida livre num fragmento de Mata Atlântica pertencentes ao gênero Callithrix, no município de Viçosa, Minas Gerais, Brasil. Entre os 19 espécimes de sagui, um estava infectado com Ehrlichia canis. Esse achado aponta para um novo hospedeiro selvagem para E. canis com grande potencial de transmissão ao homem, devido ao seu crescente contato com pessoas. Este é o primeiro relato de primata do gênero Callithrix infectado com Ehrlichia spp.

Palavras-chave: Ehrlichia, Callithrix, sagui, carrapatos.

Ehrlichiosis is transmitted to humans and animals by tick bites and is considered an emerging health problem. Ehrlichia bacteria are preserved in nature through the infection of mammals.

Classified as a Gram-negative $\alpha$-proteobacterium, Ehrlichia is an obligate intracellular parasite currently found throughout the world, with ten species described so far: E. canis, E. chaffeensis, E. ewingii, E. ruminantium, E. muris, E. equi, E. phagocytophila, E. risticii, E. ruminantium and E. sennetsu. Among these ten species, the first three and E. mineirensis (non-validated species) have been reported in Brazil, all with zoonotic potential (CRUZ et al., 2012; COWDRY, 1925; DUMLER et al., 2001;

*Corresponding author: Claudio Mafra, Laboratório de Parasitologia e Epidemiologia Molecular, Departamento de Bioquímica e Biologia Molecular, Universidade Federal de Viçosa, Av. P.H. Rolfs, CCB2, $2^{\circ}$ Andar, Sala 215 , CEP 36570-900, Viçosa, MG, Brasil, e-mail: mafra@ufv.br
FOGGIE, 1949; HOLLAND et al., 1985; LEWIS et al., 1975; VIEIRA et al., 2011; WEN et al., 1995).

The increasingly close contact between humans and wildlife populations has facilitated the spread of many infectious and parasitic agents to new hosts and environments, establishing new host-parasite relationships and new ecological niches in the chain of transmission of diseases (POGGIANI \& OLIVEIRA, 1998). Among the factors that have led to this situation is the expansion of agriculture and animal husbandry to "conservation areas," favoring the contact of domestic animals and humans with wild animals. Marmosets of the genus Callithrix are a diverse group of platyrrhine primates that are part of the Callitrichidae family. These small primates, who live in forest fragments adjacent to urbanized areas, have come into increasing contact with humans and domestic animals, creating a permanent conflict between 
human needs and wildlife habitats and health. This situation has being aggravated by the involvement of wild animals in emerging and unknown epidemiological chains, showing a potential risk to public health (FOWLER, 1986). To date, the literature contains no report about the occurrence of Ehrlichia infection in marmosets. Therefore, this paper describes and characterizes the first detection of E. canis in free-living primates of the genus Callithrix.

This study, which was conducted from March 2010 to January 2012, involved animals living in an urbanized area called Vila Gianetti, in a small preserved natural fragment of the Atlantic Forest biome ( $-20^{\circ} 45^{\prime} 16.59$ ”, $\left.-42^{\circ} 52^{\prime} 19.80^{\prime \prime}\right)$ located on the campus of the Federal University of Viçosa, in the municipality of Viçosa, state of Minas Gerais, in southeastern Brazil (20 $45^{\prime}$ S, 42 $\left.52^{\prime} \mathrm{W}\right)$.

We analyzed blood samples drawn from 19 marmosets belonging to four wild native groups. The marmosets were caught using a multiple-entry trap, weighed, and anaesthetized with ketamine hydrochloride (Vetaset, USA) at a dose of $10 \mathrm{mg} / \mathrm{kg}$ of body mass, and xylazine hydrochloride (Anasedan, Brazil) at a dose of $0.5 \mathrm{mg} / \mathrm{kg}$ of body mass (CARPENTER \& MARION, 2013). The skin and fur of all the animals were inspected for ectoparasites using a magnifying glass. After drawing the blood samples, the marmosets were kept in a warm dark room until they recovered from the effects of anesthesia. Four hours later, the animals were released into the same site where they were captured. Blood samples collected with anticoagulant were stored at $-20^{\circ} \mathrm{C}$ and the DNA was extracted using QIAmp ${ }^{\circ}$ DNA Mini Kit (Qiagen, USA), according to the manufacturer's instructions. After DNA extraction, the DNA samples were stored at $-20{ }^{\circ} \mathrm{C}$ for further analysis. Real time PCR analysis was performed in a step one real-time PCR system (Applied Biosystems, USA), using the primers ER-R1 (5'-GGAGGTAATGCACCAGCC-3') and ER5-3 (5'-GTTAGAGTTCCTTGATGG-3') which identify the specific 16S ribosomal gene for Ehrlichia genus organisms (INAYOSHI et al., 2004). E. canis DNA and deionized sterile water were used as positive and negative controls, respectively. Ct values above 35 were considered negative. Positive samples were analyzed further by nested PCR to confirm Ehrlichia species, also using 16S rRNA gene primers. For the first reaction we used the genus specific primer set ECC (5'-CGTATTACCGCGGCTGCTGGCA-3-') and ECB (5'-AGAACGAACGCTGGCGGCAAGCC-3') (DAWSON et al., 1994). For the second reaction we used EC-F (5'-CAATTATTTATAGCCTCTGGCTATAGGAA-3') ( YABSLEY e t al., 2004 ) and HE-3 (5'-CAATTGCTTATAACCTTTTGGTTATAAAT-3') (ANDERSON et al., 1992), which are known as specific primers for $E$. canis. The PCR reaction was confirmed by electrophoresis, using $1.5 \%$ agarose gel stained with ethidium bromide. To confirm the species in the amplified product, the sample was subjected to sequencing analysis (Macrogen Inc., South Korea), followed by bioinformatics analysis by BLAST (ALTSCHUL et al., 1990), comparing it with Ehrlichia DNA sequences deposited in GenBank. The nucleotide sequence obtained was deposited in GenBank under access number KC822950.1, identified by the name Ehrlichia canis isolate UFV1. A phylogenetic analysis was performed with the aid of MrBayes 3.2 application, using
Bayesian inference and the Monte Carlo method, with 2,000,000 generations, containing 4 chains and 2 runs (nchains= 4; nruns=2) (RONQUIST et al, 2012). The sequences were analyzed by comparison, using MEGA5 (TAMURA et al., 2011). ClustalW (THOMPSON et al., 1994) and FigTree v1.3.1 (RAMBAUT, 2008) applications for alignment and visualization of the phylogenetic tree. Anaplasma bovis isolate CFT-27 (2009) gene for $16 \mathrm{~S}$ ribosomal RNA (accession number AB723715.1) was used as the outgroup. To compose the dataset, we selected several Ehrlichia 16S ribosomal gene sequences deposited in GenBank, as illustrated in Figure 1.

Only one of the analyzed samples was PCR positive for Ehrlichia canis species. The amplified product was sequenced and subjected to BLAST analysis, showing $100 \%$ similarity with several E. canis sequences stored in GenBank. A Bayesian inference phylogenetic tree was constructed using the nucleotide substitution model GTR + I + G selected by the Akaike Information Criterion (AIC) (Figure 1). Two well- divided clusters were observed in this phylogenetic tree, one of them containing $E$. canis and $E$. ovina sequences, while the other cluster contained E. ewingii, E. muris, E. ruminantium and E. chaffeensis, showing $78 \%$ of posterior probability.

Monkeys are proven transmitters and hosts of many infectious agents, including a wide range of viruses and bacteria, and are susceptible to some infections common to humans (ANDRADE et al., 1999). The presence of E. canis in marmosets of the genus Callithrix sp. described here demonstrates the susceptibility of this host, which has not heretofore been listed as a possible accidental host, natural reservoir or even amplifier of $E$. canis. The groups of marmosets of this study have lived for at least three decades in an area of 75 hectares of an urban forest fragment, and have had some level of direct contact with humans through touching, by humans giving them food (bananas and cookies) and by scavenging in garbage. In free-ranging marmosets, patterns of disease acquisition may be influenced by habitat disturbance and fragmentation and by proximity to human settlements.

The phylogenetic analysis revealed that the genotype of E. canis found in the marmoset is very similar to other genotypes previously identified in several hosts, such as domestic dogs (Canis lupus familiaris), wild cats (Prionailurus bengalensis euptilurus), iriomote cats (Prionailurus iriomotensis), small spotted cats (Leopardus tigrinus), ocelots (Leopardus pardalis) and ticks (Rhipicephalus sanguineus) in various countries, including Brazil, Tunisia, Thailand, Cape Verde, Taiwan, Italy, Malaysia, Philippines, India and Romania (Figure 1).

This range of hosts demonstrates the complex relationship of the ecology of this bacterium found in different vertebrates and the risk it poses to marmosets, and to humans and domestic animals in close contact with these primates. This close association could facilitate the transmission of ehrlichiosis to humans through brown tick bites, $R$. sanguineus, from domestic dogs, and its parasitism on humans has been reported in South America (GUGLIELMONE et al., 2006). These ticks occasionally infest wild animals (DANTAS-TORRES et al., 2010). However, the brown tick parasitizing marmosets was heretofore unknown. Because ehrlichiosis is a zoonosis (CALIC et al., 2004), greater 


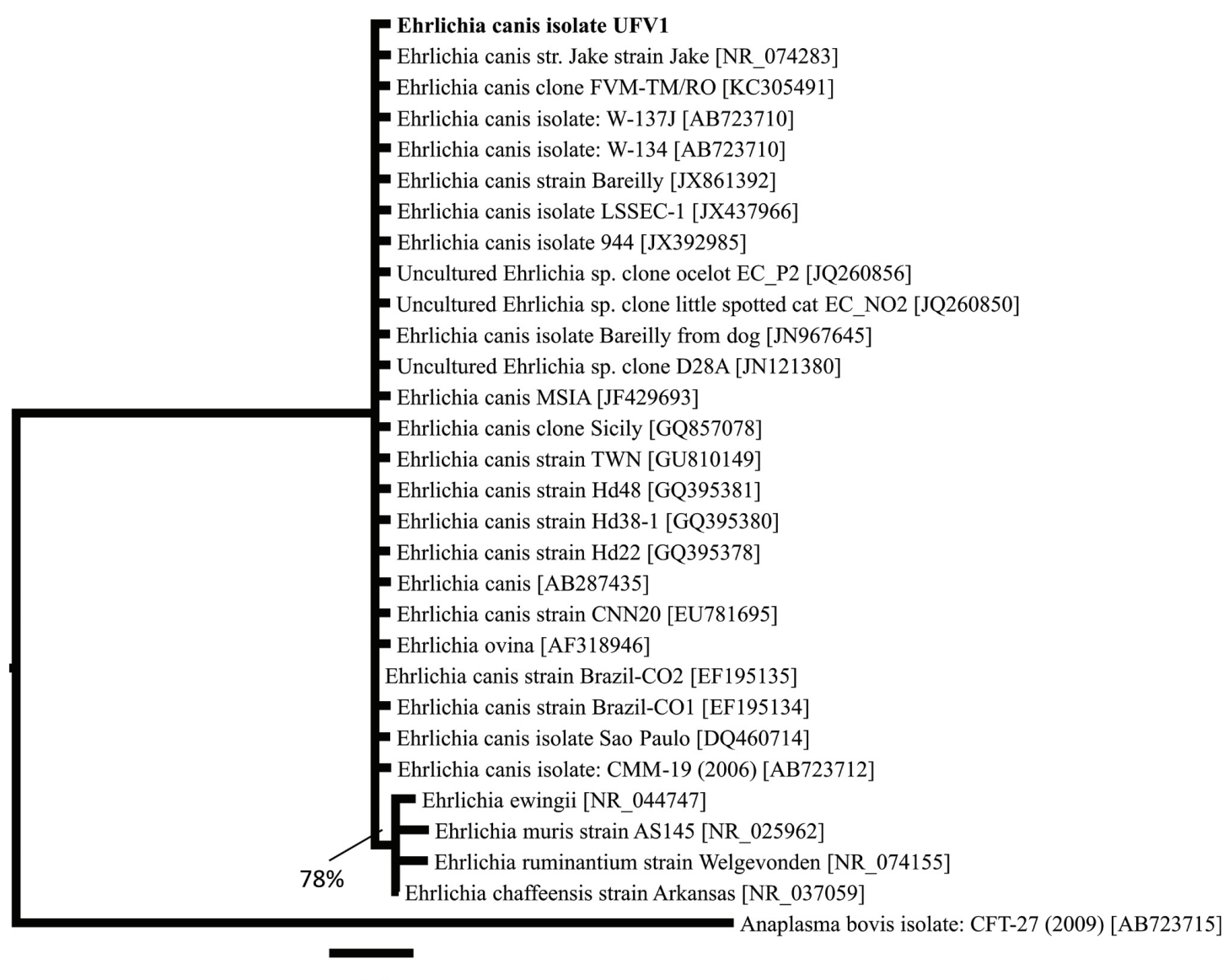

0.2

Figure 1. Phylogenetic tree by Bayesian inference for the 16S rRNA gene of Ehrlichia bacteria. A 2,000,000 generations were required for convergence using the model GTR + I + G. The discovery in the study sample is bold. The number indicates the percentage posterior probability. The acession numbers are shown in brackets. Anaplasma bovis was used as outgroup.

attention and vigilance is needed in areas where these small mammals are distributed, as well as additional studies on the health of wild animals that may participate in the peri-urban or urban cycle of this agent. With regard to the possible vector or vectors of the ehrlichiosis agent involved in the marmoset population under study, it should be noted that no ectoparasites were found during the capture campaigns.

We emphasize the importance for further studies aimed at gaining a better understanding of the natural history of this agent in interactions such as this one, and on determining whether or not Callithrix sp. primates are effectively hosts or reservoirs of ehrlichiosis amplifiers. To date, the scientific literature contains no reports about marmosets infected by Ehrlichia species. In this paper, we describe the detection and characterization of E. canis infection in free-living marmosets of the genus Callithrix. In view of these findings, there is an evident need for more studies to evaluate the role of this primate as a possible host and/or amplifier of Ehrlichia organisms and related agents in the wild and in peridomiciliary environments, which pose a risk for domestic and wild animals and for humans.

\section{References}

Altschul SF, Gish W, Miller W, Myers EW, Lipman DJ. Basic local alignment search tool. J Mol Biol 1990; 215(3): 403-410. http://dx.doi. org/10.1016/S0022-2836(05)80360-2. PMid:2231712

Anderson BE, Sumner JW, Dawson JE, Tzianabos T, Greene CR, Olson JG, et al. Detection of the etiologic agent of human ehrlichiosis by polymerase chain reaction. J Clin Microbiol 1992; 30(4): 775-780. PMid:1374076.

Andrade MCR, Oliveira AN, Romijn PC, Kimura LMS. Resposta imune produzida por vacinas anti-rábicas em sagüis (Callithrix sp). Rev Soc Bras Med Trop 1999; 32(5): 533-540. http://dx.doi.org/10.1590/ S0037-86821999000500011. PMid:10881088

Calic SB, Galvão MAM, Bacellar F, Rocha CMBM, Mafra CL, Leite RC, et al. Human ehrlichioses in Brazil: first suspect cases. Braz J Infect Dis 2004; 8(3): 259-262. http://dx.doi.org/10.1590/S141386702004000300011. PMid:15476059

Carpenter JW, Marion CJ. Exotic animal formulary. St. Louis: Elsevier; 2013. 
Cowdry EV. Studies on the Etiology of Heartwater: I. Observation of a Rickettsia, Rickettsia ruminantium (n. sp.), in the Tissues of Infected Animals. J Exp Med 1925; 42(2): 231-252. http://dx.doi.org/10.1084/ jem.42.2.231. PMid:19869049

Cruz AC, Zweygarth E, Ribeiro MF, da Silveira JA, de la Fuente J, Grubhoffer L, et al. New species of Ehrlichia isolated from Rhipicephalus (Boophilus) microplus shows an ortholog of the E. canis major immunogenic glycoprotein gp36 with a new sequence of tandem repeats. Parasit Vectors 2012; 5(1): 291. http://dx.doi.org/10.1186/1756-33055-291. PMid:23231731

Dantas-Torres F, Ferreira DR, de Melo LM, Lima PA, Siqueira DB, Rameh-de-Albuquerque LC, et al. Ticks on captive and free-living wild animals in northeastern Brazil. Exp Appl Acarol 2010; 50(2): 181-189. http://dx.doi.org/10.1007/s10493-009-9296-5. PMid:19693679

Dawson JE, Stallknecht DE, Howerth EW, Warner C, Biggie K, Davidson WR, et al. Susceptibility of white-tailed deer (Odocoileus virginianus) to infection with Ehrlichia chaffeensis, the etiologic agent of human ehrlichiosis. J Clin Microbiol 1994; 32(11): 2725-2728. PMid:7852563.

Dumler JS, Barbet AF, Bekker CP, Dasch GA, Palmer GH, Ray $\mathrm{SC}$, et al. Reorganization of genera in the families Rickettsiaceae and Anaplasmataceae in the order Rickettsiales: unification of some species of Ehrlichia with Anaplasma, Cowdria with Ehrlichia and Ehrlichia with Neorickettsia, descriptions of six new species combinations and designation of Ehrlichia equi and 'HGE agent' as subjective synonyms of Ehrlichia phagocytophila. Int J Syst Evol Microbiol 2001; 51(Pt 6): 2145-2165. http://dx.doi.org/10.1099/00207713-51-6-2145. PMid:11760958

Foggie A. Studies on tick-borne fever in sheep. J Gen Microbiol 1949; 3(1): v. PMid:18126520.

Fowler ME. Zoo \& wild animal medicine. Philadelphia: Saunders; 1986.

Guglielmone AA, Beati L, Barros-Battesti DM, Labruna MB, Nava S, Venzal JM, et al. Ticks (Ixodidae) on humans in South America. Exp Appl Acarol 2006; 40(2): 83-100. http://dx.doi.org/10.1007/s10493006-9027-0. PMid:17103085

Holland CJ, Weiss E, Burgdorfer W, Cole AI, Kakoma I. Ehrlichia risticii sp. nov.: etiological agent of equine monocytic ehrlichiosis (synonym, Potomac horse fever). Int J Syst Bacteriol 1985; 35(4): 524-526. http:// dx.doi.org/10.1099/00207713-35-4-524.
Inayoshi M, Naitou H, Kawamori F, Masuzawa T, Ohashi N. Characterization of Ehrlichia species from Ixodes ovatus ticks at the foot of Mt. Fuji, Japan. Microbiol Immunol 2004; 48(10): 737-745. http:// dx.doi.org/10.1111/j.1348-0421.2004.tb03599.x. PMid:15502406

Lewis GEJ Jr, Huxsoll DL, Ristic M, Johnson AJ. Experimentally induced infection of dogs, cats, and nonhuman primates with Ehrlichia equi, etiologic agent of equine ehrlichiosis. Am J Vet Res 1975; 36(1): 85-88. PMid:1115421.

Poggiani F, Oliveira RE. Indicadores para conservação dos núcleos de vida silvestre. Série Técnica IPEF 1998; 12(31): 45-52.

Rambaut A. FigTree v1.3.1. Tree figure drawing tool. 2008. [cited 2014 June 6]. Available from: http://tree.bio.ed.ac.uk/software/figtre?e/

Ronquist F, Teslenko M, van der Mark P, Ayres DL, Darling A, Höhna $S$, et al. MrBayes 3.2: efficient Bayesian phylogenetic inference and model choice across a large model space. Syst Biol 2012; 61(3): 539-542. http:// dx.doi.org/10.1093/sysbio/sys029. PMid:22357727

Tamura K, Peterson D, Peterson N, Stecher G, Nei M, Kumar S. MEGA5: molecular evolutionary genetics analysis using maximum likelihood, evolutionary distance, and maximum parsimony methods. Mol Biol Evol 2011; 28(10): 2731-2739. http://dx.doi.org/10.1093/ molbev/msr121. PMid:21546353

Thompson JD, Higgins DG, Gibson TJ. CLUSTAL W: improving the sensitivity of progressive multiple sequence alignment through sequence weighting, position-specific gap penalties and weight matrix choice. Nucleic Acids Res 1994; 22(22): 4673-4680. http://dx.doi.org/10.1093/ nar/22.22.4673. PMid:7984417

Vieira RF, Biondo AW, Guimarães AM, Santos AP, Santos RP, Dutra LH, et al. Ehrlichiosis in Brazil. Rev Bras Parasitol Vet 2011; 20(1): 1-12. http://dx.doi.org/10.1590/S1984-29612011000100002. PMid:21439224

Wen B, Rikihisa Y, Mott J, Fuerst PA, Kawahara M, Suto C. Ehrlichia muris sp. nov., identified on the basis of 16S rRNA base sequences and serological, morphological, and biological characteristics. Int J Syst Bacteriol 1995; 45(2): 250-254. http://dx.doi.org/10.1099/0020771345-2-250. PMid:7537059

Yabsley MJ, Norton TM, Powell MR, Davidson WR. Molecular and serologic evidence of tick-borne Ehrlichiae in three species of lemurs from St. Catherines Island, Georgia, USA. J Zoo Wildl Med 2004; 35(4): 503-509. http://dx.doi.org/10.1638/03-116. PMid:15732591 